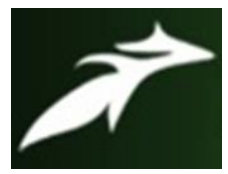

Khalilullah Zaryal et al, International Journal of Advances in Agricultural Science and Technology,

Vol.7 Issue.11, November-2020, pg. 84-90

ISSN: 2348-1358

Impact Factor: 6.057

NAAS Rating: 3.77

\title{
Effects of Crop Establishment Methods and Phosphorus Fertilization on Growth and Yield of Mungbean (Vingna radiata L. Wilczek.) in Kandahar Region of Afghanistan
}

\author{
Khalilullah Zaryal ${ }^{1}$; Shah Mahmood Barai ${ }^{2}$; Noorulhaq Mohammadi ${ }^{3}$; \\ Raz Mohammad Stori ${ }^{4}$; Nasir Ahmad Nasrat ${ }^{5}$; Sayed Ahmad Sayedi ${ }^{6}$; \\ Yamma Noori $^{7}$; Qudratullah Ehsan ${ }^{8}$; Khalid Ahmad Yaqubi ${ }^{9}$; Hayatullah Ahmadi $^{10}$ \\ ${ }^{1}$ Assistant Professor, Department of Agronomy, Faculty of Plant Science, Afghanistan National Agricultural Science and Technology University (ANASTU) \\ khalilzerialzerial@gmail.com \\ ${ }^{2}$ Senior Professor, Department of Agronomy, Faculty of Agriculture, Afghanistan National Agricultural Science and Technology University (ANASTU) \\ shahmahmood_baray@yahoo.com \\ ${ }^{3}$ Assistant Professor, Department of Agronomy, Faculty of Plant Science, Afghanistan National Agricultural Science and Technology University (ANASTU) \\ nmohammadi111@gmail.com \\ ${ }^{4}$ Associate Professor, Department of Agronomy, Faculty of Agriculture, Uruzgan University, Afghanistan \\ raz.storai@gmail.com \\ ${ }^{5}$ Associate Professor, Department of Agronomy, Faculty of Agriculture, Afghanistan National Agricultural Science and Technology University (ANASTU) \\ n.a.nasrat@gmail.com \\ ${ }^{6}$ Assistant Professor, Department of Agronomy, Faculty of Agriculture, Afghanistan National Agricultural Science and Technology University (ANASTU) \\ sayed_50099@yahoo.com \\ ${ }^{7}$ Assistant Professor, Department of Agronomy, Afghanistan National Agricultural Science and Technology University (ANASTU) \\ yammanoori2@gmail.com \\ ${ }^{8}$ Assistant Professor, Department of Agronomy, Afghanistan National Agricultural Science and Technology University (ANASTU) \\ qudrat.ehsan@gmail.com \\ ${ }^{9}$ Assistant Professor, Department of Agronomy, Faculty of Agriculture, Afghanistan National Agricultural Science and Technology University (ANASTU) \\ kyaqubi3@gmail.com \\ ${ }^{10}$ Assistant Professor, Department of Plant Protection, Faculty of Plant Science, Kandahar University, Afghanistan \\ hayatullahahmadi114@gmail.com \\ DOI: 10.47856/IJAAST.2020.v07i11.012
}

\begin{abstract}
A field experiment was conducted entitled "Effect of methods of crop establishment and phosphorus fertilization on mungbean (Vigna radiata L. Wilczek) during (August-October) of 2017 at Research Farm of Afghanistan National Agriculture Science and Technology University (ANASTU), Kandahar, Afghanistan. The experiment was laid out in a split plot design with seven treatment combinations, i.e. main plots as three crop establishment methods (Flatbed broadcast planting, raised bed planting and Flatbed row sowing) and four phosphorus application rates $(0,45,60$ and $75 \mathrm{~kg}$ $\mathrm{P}_{2} \mathrm{O}_{5}$ ). The experimental findings indicated that the growth attributes, plant height $(\mathrm{cm})(41.9)$, number of branch plant ${ }^{-1}(4.8)$, dry matter accumulation $\left(\mathrm{g} / \mathrm{m}^{2}\right)(481.5)$, root dry weight $(\mathrm{g})$ plant $^{-1}(1.53)$, leaf area index (3.56) and yield, i.e. grain yield $(1,424 \mathrm{t} / \mathrm{ha})$, stover yield (4,203 t/ha), biological yield (5,627 t/ha) and harvest index $(24.8 \%)$ were significantly enhanced due to raised bed plating method along with application of $75 \mathrm{~kg} \mathrm{P}_{2} \mathrm{O}_{5}$, whereas the minimum growth attributes and yield was obtained in the plots cultivated as flatbed broadcast planting method with no phosphorus application level.

KEYWORDS: Mungbean, Growth, Crop, Phosphorous, Yield.
\end{abstract}

Based on a part of M.Sc. Thesis of the first author, submitted jointly to ANASTU and ICAR-Indian Agricultural Research Institute, New Delhi 110012 in 2017 (Unpublished)

Corresponding author's email: khalilzerial@gmail.com 


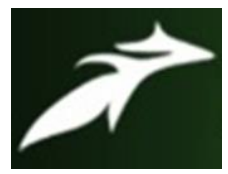

Khalilullah Zaryal et al, International Journal of Advances in Agricultural Science and Technology,

Vol.7 Issue.11, November-2020, pg. 84-90

ISSN: 2348-1358

Impact Factor: 6.057

NAAS Rating: 3.77

\section{INTRODUCTION}

Mungbean is botanically known as Vingna radiata L. Wilczek. It is an important pulse crop worldwide. It is widely cultivated across the semi-arid to sub humid low land tropical and sub-tropical regions. Mungbean is believed to be originated in south and south-east Asia (India, Myanmar, Thailand). It is an annual crop with erect and highly branched stem which grows about 60 to $75 \mathrm{~cm}$ tall. It is an excellent and inexpensive source of vegetable protein and ranks high among the different pulse crops, grown in the world. Mature seeds are rich in proteins, and cooked seeds form a valuable constituent of diet of considerable number of people in country.

The seed of mungbean contains $51 \%$ carbohydrate, $26 \%$ protein, $10 \%$ moisture, 3\% mineral and 3\% vitamins (Kaul, 1982) and can easily be cooked. It constitutes an essential supplement in cereal based diet of human beings. The biological value of human diet improves greatly, when wheat or rice is combined with mungbean because of the complementary relationship of the essential amino acids. Mungbean is particularly rich in leucine, phenylalanine, lysine, valine, isoleucine, etc. In addition to being an important source of human food and animal feed. Apart from seed purpose mungbean is also used as greenmanuring crop.

Generally, Vigna radiata is sown in warm region of Afghanistan like Kunduz, Helmand, Kandahar, Nangarhar, Parwan, Baghlan, Laghman, Takhar, Kapisa, etc. (Noorzaie, 2017). To maintain the level of pulses consumption in a balanced diet the Government of Afghanistan has to spend huge amount of foreign currency for importing pulses every year. Therefore, it is necessary to put efforts to improve and enhance production of mungbean in the country.

Therefore a field experiment conducted on the title of "Effect of methods of crop establishment and phosphorus fertilization on mungbean (Vigna radiate. L) in Kandahar Region of Afghanistan".

\section{MATERIAL AND METHODS:}

The experiment was conducted to study the effect of methods of crop establishment methods and phosphorus fertilization on mungbean during August, 2017 to October, 2017 in summer season at the Experimental Farm of Afghanistan National Agricultural Science \& Technology University (ANASTU), Kandahar (Afghanistan), situated in southern part of the country having semi-arid climate.

The soil of the experimental field was sandy clay loam in texture with pH 7.23 and Electric Conductivity 0.15 (EC Mater). The content of $\mathrm{NH}_{4}-\mathrm{N}$ and $\mathrm{NO}_{3}-\mathrm{N}\left(\mathrm{mg} \mathrm{kg}^{-1}\right)$, and available $\mathrm{P}\left(\mathrm{kg} \mathrm{ha}^{-1}\right)$ were 32.2, 36.2 and 23.0 respectively (by LaMotte Soil Test Kit). The experiment was laid out in split plot design (SPD) combined with three replications. The experimental treatments were of three crop establishment methods (i. Flatbed broad cast planting ii. Raised Bed Planting iii. Flatbed Row Sowing) and four levels of phosphorous treatments such as 0 (T1), 45 (T2), 60 (T3) and 75 (T4) kg ha ${ }^{-1}$ was worked out with a mungbean variety (NM-94). The planting methods were allocated to main plots and phosphorus levels to subplots. however, $150 \mathrm{~kg} \mathrm{ha}^{-1}$ DAP (Diammonium-Phosphate) fertilizer was used on the sowing time to all plots equally, thus absolute control plots were not presented in the experiment. Basal application comprised of recommended dose of $\mathrm{N}$ and potash for mungbean while phosphorus was applied as per treatments. $\mathrm{N}$ was supplied through urea and $\mathrm{DAP}$, while $\mathrm{P}_{2} \mathrm{O}_{5}$ and $\mathrm{K}_{2} \mathrm{O}$ were supplied through DAP and potassium sulfate, respectively. Application of potassium sulphate as a source of potash also supplied sulphar@12.75 $\mathrm{kg} \mathrm{ha}^{-1}$.

The plant spacing was $30 \mathrm{~cm} \times 15 \mathrm{~cm}$, which accommodated 7 rows/plot and 80 plants/row, while using seed @ 25 kg ha ${ }^{-1}$. One border row from both the sides of each plot as well as one sample row from one side of the plot was discarded, besides, $20 \mathrm{~cm}$ crop rows from other two sides as border effect in the row/line sowing, while, to reduce the border effect a $25 \mathrm{~cm} \mathrm{crop}$ was discarded from all borders in case of flatbed broadcast planting. The net plot size was $1.8 \mathrm{~m} \times 3.6 \mathrm{~m}$ i.e. $6.48 \mathrm{~m}^{2}$ in case of raised bed planting along with flatbed row sowing; and $2.65 \mathrm{~m} \times 3.5 \mathrm{~m}$ i.e. $9.27 \mathrm{~m}^{2}$ in case of flatbed broadcast planting.

\section{RESULTS AND DISCUSSION:}

\section{Growth attributes and yield}

The effect of different crop establishment methods and phosphorus application levels on Plant height (cm), Number of Branches plant ${ }^{-1}$, Dry matter accumulation (g) plant ${ }^{-1}$, Root dry weight (g), Leaf area index (LAI), grain yield, stover yield, biological yield and harvest index of mungbean plant was studied under semi-arid conditions of Kandahar during summer season of 2017. The result obtained are presented and discussed as follow: 


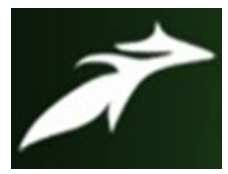

Khalilullah Zaryal et al, International Journal of Advances in Agricultural Science and Technology,

Vol.7 Issue.11, November-2020, pg. 84-90

ISSN: 2348-1358

Impact Factor: 6.057

NAAS Rating: 3.77

\section{Plant height (cm)}

The data presented in table-1 on growth attributes of mungbean crop during experimentation period, were significantly affected due to different crop establishment methods and phosphorus application rates. Raised bed planting and flatbed row sowing methods resulted significantly higher plant height over flatbed broadcast planting method at all the growth stages (except 30 DAS). Same variations in growth attributes due to methods of crop establishment has been reported by Jat and Ahlawat et al. (2001), Ahmad et al. (2012) and Girase et al. (2016). Similarly, effect of $60 \mathrm{~kg} \mathrm{P}_{2} \mathrm{O}_{5} \mathrm{ha}^{-1}$ was significant on plant height over control at all the growth stages $(14.9 \mathrm{~cm}, 38.2$ and $40.6 \mathrm{~cm}$ at 30 DAS, 60 DAS and at harvest). Enhancement of plant height with application of $75 \mathrm{~kg} \mathrm{P}_{2} \mathrm{O}_{5}$ ha $^{-1}$ was significantly higher over control and $45 \mathrm{~kg}_{2} \mathrm{O}_{5} \mathrm{ha}^{-1}$ at all the growth periods except 30 DAS. $60 \mathrm{~kg} \mathrm{P}_{2} \mathrm{O}_{5} \mathrm{ha}^{-1}$ was found at par to $75 \mathrm{~kg} \mathrm{P}_{2} \mathrm{O}_{5} \mathrm{ha}^{-1}$. Gajera et al. (2014) and Kumar et al. (2012) also reported that application of phosphorus significantly affects the plant height of mungbean plant.

\section{Number of Branches plant ${ }^{-1}$}

Different Crop establishment methods significant affects number of branches plant ${ }^{-1}$ of mungbean, which was observed at all the growth stages (Table-1). The highest number of branches plant ${ }^{-1}$ were found in raised bed planting method at all the growth stages, whereas the lowest number of branches plant ${ }^{-1}$ were observed in flatbed broadcast planting method. Jat and Ahlawat (2001), and Shete et al. (2010), also observed result similar to the present findings. Application of phosphorus also had positive effect on numbers of branches plant ${ }^{-1}$ of mungbean. The highest numbers of branches plant ${ }^{-1}$ were resulted with application of $75 \mathrm{~kg} \mathrm{P}_{2} \mathrm{O}_{5} \mathrm{ha}^{-1}$ which remained statistically at par to $60 \mathrm{~kg} \mathrm{P}_{2} \mathrm{O}_{5} \mathrm{ha}^{-1}$ at all the growth stages except 30 DAS. Ali et al. (1993), Shukla and Dixit (1996) also observed the effects of $\mathrm{P}_{2} \mathrm{O}_{5}$ ha $^{-1}$ on mungbean plant at different growth stages.

\section{Dry matter accumulation (g) plant ${ }^{-1}$}

The dry matter accumulation $(\mathrm{g})$ plant $^{-1}$ of mungbean was markedly affected by various crop establishment methods at all the growth stages (Table-1). Raised bed planting method and flatbed row sowing showed in significantly higher dry matter accumulation $(\mathrm{g})$ plant $^{-1}$ at all the growth stages over flatbed broadcast planting method. The similar experiment results were observed by Shete et al. (2010), Jat and Ahlawat (2001). The dry matter accumulation (g) plant ${ }^{-1}$ of mungbean was significantly influenced by different levels of phosphorus at all the growth stages except 30 DAS. The maximum dry matter accumulation (g) plant ${ }^{-1}$ was obtained in $75 \mathrm{~kg} \mathrm{P}_{2} \mathrm{O}_{5}$ ha $^{-1}$ at all the growth stages $(466.3 \mathrm{~g}, 521.3 \mathrm{~g}$ at 60 DAS and at harvest respectively) except 30 DAS and it remained at par to $60 \mathrm{~kg}_{2} \mathrm{O}_{5}$ ha $^{-1}$. The lowest dry matter accumulation plant ${ }^{-1}$ was resulted in the plots not treated with $\mathrm{P}_{2} \mathrm{O}_{5} \mathrm{ha}^{-1}$. Similarly, Owla et al. (2007) and Gajera et al. (2014) reported the positive effect of phosphorus on mungbean dry matter accumulation.

\section{Root dry weight (g)}

The highest root dry weight plant ${ }^{-1}$ was produced in raised bed planting method $(0.75 \mathrm{~g}, 0.38 \mathrm{~g}, 1.53 \mathrm{~g}$, at 30 DAS, 60 DAS and at harvest respectively), but the lowest root dry weight plant ${ }^{-1}$ was observed in flatbed broadcast crop establishment method. Flatbed row sowing showed the best result on root dry weight plant $^{-1}$ of mungbean as compared to raised bed planting method, but raised bed planting method was statistically better. Different phosphorus levels remarkably improved root dry weight plant ${ }^{-1}$ of mungbean at all the growth stages. Application of $45 \mathrm{~kg} \mathrm{P}_{2} \mathrm{O}_{5}$ ha $^{-1}$ had significant effect on root dry

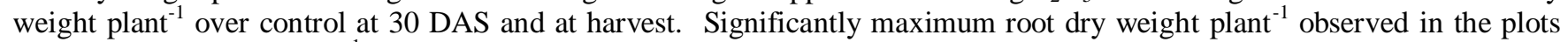
treated with $75 \mathrm{~kg} \mathrm{P}_{2} \mathrm{O}_{5} \mathrm{ha}^{-1}(0.80 \mathrm{~g}, 0.34 \mathrm{~g}, 1.61 \mathrm{~g}$, at $30 \mathrm{DAS}, 60 \mathrm{DAS}$ and at harvest respectively). The minimum root dry weight plant ${ }^{-1}$ was recorded in the plots treated with no phosphorus level at all the growth stages (Table-1). Shete et al. (2010) and Girase et al. (2016) also observed similar results.

\section{Leaf area index (LAI)}

Maximum leaf area index of munbean was recorded in raised and flatbed, and it was significantly improved over flatbed broadcast planting method at all the growth stages (Table-1). Different phosphorus levels had positively increased leaf area index of munbean at various stages of crop growth. Maximum leaf area index (3.67 at 60 DAS respectively) was found in the plots treated with $75 \mathrm{~kg} \mathrm{P}_{2} \mathrm{O}_{5}$ ha $^{-1}$. The same results were recorded by Jat and Ahlawat (2001), Amanullah et al. (2012). 


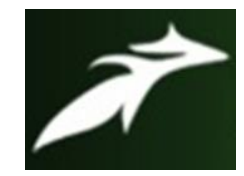

Khalilullah Zaryal et al, International Journal of Advances in Agricultural Science and Technology,

Vol.7 Issue.11, November-2020, pg. 84-90

ISSN: 2348-1358

Impact Factor: 6.057

NAAS Rating: 3.77

\section{Grain yield}

Grain yield of mungbean significantly improved due to various crop establishment methods. The remarkably higher grain yield was recorded in raised bed planting method and was at par with flatbed row sowing method, whereas the minimum grain yield was recorded in flatbed broadcast planting method (Table-1). Rasheed et al. (2003), Shaikh et al. (1994), Majid et al. (1986) and Amin et al. (2006) also found similar results. Application of different phosphorus levels also significantly raised the grain yield. Application of $75 \mathrm{~kg} \mathrm{P}_{2} \mathrm{O}_{5} \mathrm{ha}^{-1}$ resulted significantly maximum grain yield of mungbean over control and $45 \mathrm{~kg} \mathrm{P}_{2} \mathrm{O}_{5} \mathrm{ha}^{-1}$ respectively, whereas, application of $60 \mathrm{~kg} \mathrm{P}_{2} \mathrm{O}_{5} \mathrm{ha}^{-1}$ was at par to $75 \mathrm{~kg} \mathrm{P}_{2} \mathrm{O}_{5} \mathrm{ha}^{-1}$. Prasad et al. (2014) and Jahish et al., (2017) also found $60 \mathrm{~kg} \mathrm{P}_{2} \mathrm{O}_{5} \mathrm{ha}^{-1}$ as optimum dose for better grain yield of mungbean.

\section{Stover yield}

Due to various crop establishment methods, higher stover yield was recorded in raised bed planting method. The lowest stover yield was obtained in flatbed broadcast planting method. Flatbed row sowing showed the best influence with stover yield at all the growth and yield attributes (Table-1). The same results were observed by Leyenaar and Hunter. (1977) and Rasheed et al. (2003). Application of different phosphorus levels had positive effect on the stover yield of mungbean. Maximum stover yield of mungbean was recorded in plots treated $75 \mathrm{~kg} \mathrm{P}_{2} \mathrm{O}_{5} \mathrm{ha}^{-1}$ where the minimum stover yield was observed in control plots, $60 \mathrm{~kg} \mathrm{P}_{2} \mathrm{O}_{5}$ ha $^{-1}$ was found at par to $75 \mathrm{~kg} \mathrm{P}_{2} \mathrm{O}_{5}$ ha $^{-1}$. Khan et al. (2002) found the similar results.

\section{Biological yield $\left(\mathrm{t} \mathrm{ha}^{-1}\right)$}

The biological yield was meaningfully affected by different crop establishment methods. Raised bed planting method produced maximum biological yield. Various phosphorus levels resulted in positive effect on biological yield. Increase in phosphorus rates significantly improved the biological yield up to $75 \mathrm{~kg} \mathrm{P}_{2} \mathrm{O}_{5} \mathrm{ha}^{-1}$. The higher biological yield was recorded with application of $75 \mathrm{~kg} \mathrm{P}_{2} \mathrm{O}_{5} \mathrm{ha}^{-1}$ while the lowest biological yield was obtained in control plots respectively (Table-1). Amanullah et al. (2012) reported that $60 \mathrm{~kg} \mathrm{P}_{2} \mathrm{O}_{5} \mathrm{ha}^{-1}$ in mungbean was resulted in higher biological yield.

\section{Harvest index}

The data presented in the table shows that, raised bed planting method recorded better harvest index of mungbean. The minimum harvest index was observed in flatbed broadcast planting method. Flatbed row sowing was at par with raised bed planting method, but raised bed planting method was numerically superior than flatbed row sowing method respectively. Identical observation was recorded by Rasheed et al. (2003), Bakht et al. (2006) and Jehan et al. (2011). Different rates of phosphorus also remarkably increase the harvest index. Addition of $60 \mathrm{~kg} \mathrm{P}_{2} \mathrm{O}_{5} \mathrm{ha}^{-1}(25.3 \%)$ resulted in highest harvest index. Tahir et al. (2015), Sardar (2002) and Parvez et al. (2013) also observed the same records from their experiments. 


\section{$\vec{x}$}

Khalilullah Zaryal et al, International Journal of Advances in Agricultural Science and Technology,

Vol.7 Issue.11, November-2020, pg. 84-90

ISSN: 2348-1358

Impact Factor: 6.057

NAAS Rating: 3.77

\begin{tabular}{|c|c|c|c|c|c|c|c|c|c|c|c|c|c|c|c|c|c|c|}
\hline \multirow{2}{*}{ Treatment } & \multicolumn{3}{|c|}{ Plant height } & \multicolumn{3}{|c|}{ Number of branch plant ${ }^{-1}$} & \multicolumn{3}{|c|}{$\begin{array}{l}\text { Dry matter accumulation } \\
\qquad\left(\mathrm{g} / \mathrm{m}^{2}\right)\end{array}$} & \multicolumn{3}{|c|}{ Root dry weight (g) plant ${ }^{-1}$} & \multicolumn{2}{|c|}{$\begin{array}{l}\text { Leaf area index } \\
\text { (LAI) }\end{array}$} & \multirow{2}{*}{ 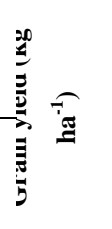 } & \multirow{2}{*}{ 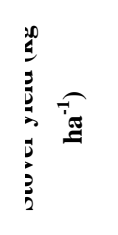 } & \multirow{2}{*}{ 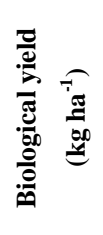 } & \multirow{2}{*}{ 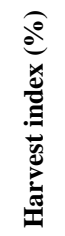 } \\
\hline & $\begin{array}{c}30 \\
\text { DAS }\end{array}$ & $\begin{array}{c}60 \\
\text { DAS }\end{array}$ & $\begin{array}{c}\text { At } \\
\text { harvest }\end{array}$ & $\begin{array}{c}\text { 30 } \\
\text { DAS }\end{array}$ & $\begin{array}{c}60 \\
\text { DAS }\end{array}$ & $\begin{array}{c}\text { At } \\
\text { harvest }\end{array}$ & $\begin{array}{c}30 \\
\text { DAS }\end{array}$ & $\begin{array}{c}60 \\
\text { DAS }\end{array}$ & $\begin{array}{c}\text { At } \\
\text { harvest }\end{array}$ & $\begin{array}{c}30 \\
\text { DAS }\end{array}$ & $\begin{array}{c}60 \\
\text { DAS }\end{array}$ & $\begin{array}{c}\text { At } \\
\text { harvest }\end{array}$ & $\begin{array}{c}30 \\
\text { DAS }\end{array}$ & $\begin{array}{c}60 \\
\text { DAS }\end{array}$ & & & & \\
\hline \multicolumn{19}{|l|}{ Crop Establishment } \\
\hline Flatbed broadcast planting & 14.1 & 36.2 & 38.2 & 1.6 & 3.3 & 3.7 & 22.9 & 380.0 & 435.5 & 0.54 & 0.33 & 0.92 & 0.35 & 3.17 & 1,137 & 3,824 & 4,961 & 22.4 \\
\hline Raised Bed Planting & 14.2 & 38.1 & 41.9 & 2.4 & 4.0 & 4.8 & 26.1 & 414.7 & 481.5 & 0.75 & 0.38 & 1.53 & 0.48 & 3.56 & 1,424 & 4,203 & 5,627 & 24.8 \\
\hline Flatbed Row Sowing & 15.4 & 36.2 & 40.0 & 1.8 & 3.5 & 4.1 & 23.5 & 379.5 & 454.0 & 0.68 & 0.31 & 1.37 & 0.53 & 3.49 & 1,305 & 4,053 & 5,358 & 23.9 \\
\hline SEm \pm & 0.07 & 0.92 & 1.30 & 0.12 & 0.17 & 0.04 & 0.39 & 6.92 & 9.77 & 0.04 & 0.05 & 0.07 & 0.008 & 0.09 & 20.6 & 89.6 & 125.8 & 0.98 \\
\hline $\mathrm{CD}(\mathrm{P}=0.05)$ & 0.28 & 3.67 & 5.21 & 0.41 & 0.40 & 0.26 & 1.57 & 27.91 & NS & NS & 0.02 & 0.32 & 0.03 & NS & 83.5 & 353.9 & 493.1 & 1.01 \\
\hline \multicolumn{19}{|l|}{ Phosphorus Rates } \\
\hline Control & 13.7 & 34.9 & 38.8 & 1.6 & 3.1 & 3.8 & 18.6 & 261.0 & 331.7 & 0.50 & 0.32 & 0.96 & 0.20 & 2.98 & 774 & 3,177 & 3,951 & 19.4 \\
\hline $45 \mathrm{~kg} \mathrm{P}_{2} \mathrm{O}_{5} / \mathrm{ha}$ & 14.3 & 36.2 & 39.9 & 1.9 & 3.5 & 4.2 & 25.5 & 387.0 & 463.0 & 0.62 & 0.31 & 1.04 & 0.46 & 3.38 & 1,296 & 4,006 & 5,303 & 24.4 \\
\hline $60 \mathrm{~kg} \mathrm{P}_{2} \mathrm{O}_{5} / \mathrm{ha}$ & 14.9 & 38.2 & 40.6 & 2.1 & 3.8 & 4.3 & 26.0 & 451.3 & 512.0 & 0.72 & 0.31 & 1.44 & 0.37 & 3.57 & 1,523 & 4,436 & 5,960 & 25.3 \\
\hline $75 \mathrm{~kg} \mathrm{P}_{2} \mathrm{O}_{5} / \mathrm{ha}$ & 16.3 & 39.3 & 41.3 & 2.2 & 3.9 & 4.6 & 26.4 & 466.3 & 521.3 & 0.80 & 0.34 & 1.61 & 0.32 & 3.67 & 1,562 & 4,486 & 6,048 & 25.0 \\
\hline SEm \pm & 0.09 & 1.18 & 1.28 & 0.22 & 0.19 & 0.16 & 0.18 & 13.95 & 14.71 & 0.04 & 0.01 & 0.14 & 0.006 & 0.06 & 24.3 & 82.3 & 114.6 & 0.38 \\
\hline $\mathrm{CD}(\mathrm{P}=0.05)$ & 0.26 & 3.54 & 3.89 & NS & 0.57 & 0.38 & 0.56 & 41.83 & 44.86 & 0.12 & 0.01 & 0.40 & 0.02 & 0.19 & 72.6 & 247.9 & 341.6 & 1.12 \\
\hline
\end{tabular}

\section{Table-1}




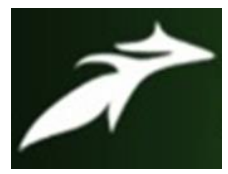

Khalilullah Zaryal et al, International Journal of Advances in Agricultural Science and Technology,

Vol.7 Issue.11, November-2020, pg. 84-90

ISSN: 2348-1358

Impact Factor: 6.057

NAAS Rating: 3.77

\section{Conclusion}

1. Raised bed planting method along with flatbed row sowing method of mungbean was superior in terms of growth, yield and economics than flatbed broadcast planting method.

2. Significantly highest grain yield, gross returns, net returns and benefit: cost ratio of mungbean was recorded with $75 \mathrm{~kg} \mathrm{P}_{2} \mathrm{O}_{5} \mathrm{ha}^{-1}$. For almost all the parameters $60 \mathrm{~kg} \mathrm{P}_{2} \mathrm{O}_{5} \mathrm{ha}^{-1}$ remained statistically at par to $75 \mathrm{~kg} \mathrm{P}_{2} \mathrm{O}_{5} \mathrm{ha}^{-1}$.

3. Interaction effect between methods of crop establishment and phosphorus levels was non-significant.

According to the findings of the study, raised bed planting method along with flatbed row sowing method and application of $60 \mathrm{~kg} \mathrm{P}_{2} \mathrm{O}_{5} \mathrm{ha}^{-1}$ can be recommended for mungbean, higher productivity and profitability.

\section{REFERENCES}

[1]. Ahlawat, S. S., Sharma, D. P., Panda, P. C., 2001. Effect of feeding poultry viscera meal on carcass traits of broiler rabbits. Indian J. Anim. Res., 35 (2): 141-143.

[2]. Amanullah, Jan., Khurshed, Alam., Amanullah \& Stewart, B. A. 2012. Mungbean response to tillage systems and phosphorus management under moisture stress condition. Journal of Plant Nutrition 35 (1): 21 - 33.

[3]. Amin, Mohammad., Abdul Razzaq., Rahmatullah. And Muhammad Ramzan. 2006. Effect of planting methods, seed density and nitrogen phosphorus (NP) fertilizer levels on sweet corn (Zea mays L.). Journal of Research (Science), Bahauddin Zakariya University, Multan, Pakistan 17 (2): 83 - 89.

[4]. Bakht, Jehan., Shakeel, Ahmad., Mohammad, Tariq., Habib, Akber. and Mohammad, Shafi. 2006. Response of maize to planting methods and fertilizer Nitrogen. Journal of Agricultural and Biological Science 1 (3): 8 - 14.

[5]. F.A.O. 2016. International year of pulses, http://www.fao.org/pulses-2016/en/

[6]. Gajera, R. J., Khafi, H. R., Raj, A. D., Yadav, V. and Lad, A. N. 2014. Effect of phosphorus and bio-fertilizers on growth, yield and economics of summer green gram (Vigna radiata L. Wilczek) Agriculture Update 9 (1): 98-102.

[7]. Girase. P.P., Dhonde, M. B. and Bhakare, B. D. 2016. Productivity, quality and economics of Ashwagandha (Withania somnifera) as influence by planting methods, spacings and nutrient management under drip irrigation. Indian Journal of Agronomy 61 (1): 94-100.

[8]. Jahish, F, Bana, RS, and Choudhary, A.K. 2017. Influence of different phosphorus levels on growth, productivity and profitability of mungbean in semi-arid regions of South Afghanistan Annals of Agricultural Research 38 (3): 351-356.

[9]. Jat, H.S. and Ahlawat, I.P.S. 2001. Effect of land configuration, post-monsoon irrigation and fertilizer application on pigeon pea (Cajanuscajan). Agronomy Digest 1:52 - 55.

[10]. Kaul, A. 1982. Pulses in Bangladesh. BARC (Bangladesh Agricultural Research Council), Farmgate, Dhaka, p. 27.

[11].Khan, M.A., Aslam, M., Tariq, Sultan. and Mahumood, I.A. 2002. Response of phosphorus application on growth and yield of inoculated and un inoculated mungbean (Vigna radiata). International Journal of Agriculture \& Biology 4 (4): 532 - 34.

[12].Kumar, Rakesh., Singh, Y.V., Singh, Surendra., Latare, A.M., Mishra, P.K. and Supriya 2012. Effect of phosphorus and sulphur nutrition on yield attributes, yield of mungbean (Vigna radiata L. Wilczek). Journal of Chemical and Pharmaceutical Research 4 (5): $2571-73$.

[13].Leyenaar, P. and Hunter, R.B. 1977. Effect of seed bed preparation on maize production in the coastal savanna zone of Ghana, Ghana Journal Agricultural Science 10 (1) 47 - 51.

[14].Majid, A., Shafiq, M. and Iqbal, M. 1986. Deep tillage and sowing techniques in maize production under high rainfed conditions. Pakistan Journal Agricultural Research 7 (1): 181 - 85.

[15]. Owla, R.L., Chavan, B.N. and Singh, Ummed. 2007. Effect of plant densities and phosphorus levels on growth and yield of green gram (Vign aradiata L.). Annals of Agricultural Research 28 (1): 95-97.

[16].Parvez, M.T., Paul, S.K. and Sarkar, M.A.R. 2013. Yield and yield contributing characters of mungbean as affected by variety and level of phosphorus. Journal of Agroforestry and Environment 7 (1): 115 - 18.

[17].Prasad, S.K., Singh, M.K. and Jay Singh. 2014. Response of rhizobium inoculation and phosphorus levels on mungbean (Vigna radiata) under guava-based Agrihorti system. Save Nature to Survive 9 (2): $557-60$.

[18].Rasheed, Muhammad., Mahmood, Tariq. And Nazir, Muhammad. Shafi. 2003. Response of hybrid maize to different planting methods and nutrient management. Pakistan. Journal of Agriculture 40 (1-2): 39 - 42.

[19].Sardar, M. S. U. 2002. Influence of plant density and phosphorus and inoculation on the growth and yield of mungbean (cv. BINAmoog2). M.Sc. in Agronomy. Thesis, Department. Agronomy., Bangladesh Agricultural. University. Mmensingh. p. 52.

[20]. Shaikh, A. A., Jadhav, A. S., Koli, B. D. and Wattamwar, M. J. 1994. Effects of planting layouts, mulching and fertilizers on dry matter accumulation and energy relationship in rainfed pearl millet. Journal. Mah. Agricultural. University 19: 421 - 23. 


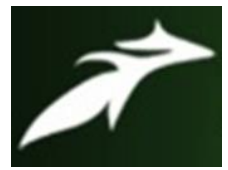

Khalilullah Zaryal et al, International Journal of Advances in Agricultural Science and Technology,

Vol.7 Issue.11, November-2020, pg. 84-90

ISSN: 2348-1358

Impact Factor: 6.057

NAAS Rating: 3.77

[21].Shete, P.G., Baviskar, V. S. and adhav, s. 1. 2010. Effect of land configuration, inorganic fertilizers and levels of FYM on quality and nutrient status of rabigreengram. International Journal of Agricultural Sciences, 6 (2): 546 - 48.

[22]. Shukla, S. K. and Dixit, R. S. 1996. Effect of rhizobium inoculation, plant population and phosphorus on growth and yield of summer mungbean (Vignaradiata). Indian. Journal. Agronomy. 41 (4): 611 - 15.

[23]. Tahir, M., Khalid, U. B. and Waseem, M. 2015. Evaluation of variation in benefit cost ratio and yield of mungbean (Vigna radiata L.) due to influence of different sources and levels of phosphorus. ISSN 1808-2882, 11 (1): 23 - 34

\begin{tabular}{|c|l|l|}
\hline S/N & \multicolumn{3}{|c|}{ Personal Information } \\
\hline 1 & Name & Khalilullah Zaryal \\
\hline 2 & F/Name & Atiqullah \\
\hline 3 & Date of Birth & 12-30-1992 \\
\hline 4 & Place of Birth & Kandahar, Afghanistan \\
\hline 5 & Occupation & $\begin{array}{l}\text { Assistant Professor, Department of Agronomy, } \\
\text { Faculty of Plant Science, Afghanistan National } \\
\text { Agricultural Science and Technology University } \\
\text { (ANASTU) }\end{array}$ \\
\hline 6 & Address & Kandahar City, Kandahar, Afghanistan \\
\hline 7 & Email/Phone & khalilzerial @ gmail.com \\
\hline
\end{tabular}

